\title{
The Syrian Steppe: Past Trends, Current Status, and Future Priorities
}

\section{By Mounir Louhaichi and Adrienne Tastad}

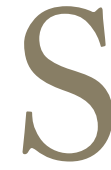
yria's rangelands are vitally important both ecologically and economically, and they also have significant cultural and heritage values for Bedouin communities. ${ }^{1}$ Rangelands are the country's largest land-use category. The Syrian steppe covers approximately 10.5 million hectares, over half the country's landmass ${ }^{2}$ (Fig. 1). The Badia, as it is known in Arabic, is largely populated by seminomadic Bedouin people whose main occupation is herding sheep ${ }^{3}$ (Fig. 2). In addition to serving as the resource base for animal production (a key source of income and livelihoods), rangelands provide a range of ecological services, such as nutrient cycling, pollutant filtering, and biodiversity preservation. ${ }^{4-6}$ Complex political, social, and environmental factors have resulted in the progressive degradation of the Badia ecosystem over the last 50 years. This degradation, caused by over-exploitation and unsustainable, poorly planned use of resources, is amplified by harsh ecological conditions, including frequent droughts. ${ }^{2,7}$ In such environments, unchecked degradation often results in desertification - a serious and irreversible threat with drastic consequences for the livelihoods of those dependent on rangelands. There are large spatial differences in the importance, intensity, and extent of land degradation in Syria, depending on a number of variables, including human and livestock density, ${ }^{8}$ living standards and conditions, and past and current management practices. ${ }^{9}$ The management of these rangelands, now and into the future, is therefore critical to the national economy. Past management practices have led to degradation of large rangeland areas, calling into question their long-term sustainability under current usage practices.

\section{Climate, Vegetation, and Soil}

Most of the Badia rangeland areas fall within arid and semiarid zones characterized by wide variability in rainfall and temperature (Fig. 1). There are no clearly defined boundaries, because they shift depending on climatic conditions. Many areas adjacent to the Badia should be managed in similar ways, and, indeed, many of the ecological, economic, and social issues in these adjacent areas are similar to those in the Badia. Generally, rainfall is low, erratic, and poorly distributed, with large spatial, seasonal, and annual variations. The distribution and beginning of the rainfall season may determine vegetative composition in a given year. In most years, rainfall is below average $(127 \mathrm{~mm}$ annually, over 42 years in Palmyra), and extended dry periods are common. Droughts are common, resulting in lower forage and crop productivity and water scarcity. Summer in the Badia is long, dry, and hot, with temperatures sometimes in excess of $45^{\circ} \mathrm{C}$ in July and August. The effects of high temperatures are aggravated by dry winds, or sirocco, which may occur during the growing season, making the steppe an exceedingly hostile environment. ${ }^{10}$

Because of the frequency of drought years, Badia vegetation is composed primarily of dwarf shrubs, with a few annual forbs and grasses. The most common species are $P o a$ bulbosa, Anabasis syriaca, and Artemisia herba-alba. The main shrub species (A. syriaca and Noaea mucronata), which dominate the landscape, are unpalatable for sheep and used only for fuel (Fig. 3). ${ }^{10}$

The soils of Syria are spread over five orders of the United States Department of Agriculture Soil Taxonomy. ${ }^{11}$ The dominant soil type in the Badia is aridisols, which cover $47.5 \%$ of the country, generally occurring where the annual rainfall is below $250 \mathrm{~mm} .{ }^{12}$ They are mostly characterized by calcic or gypsic horizons close to the surface, weak structure, and relatively light texture, which predisposes them to erosion.

\section{Changes in Pastoral Practice}

Until the end of the 1940s, most of the Bedouin occupying the Syrian steppe were fully nomadic, relying on natural grazing as feed for their flocks. ${ }^{13}$ Their nomadic lifestyle was well suited to the harsh environment of the Badia, and the traditional Hema system-a sort of rotational grazing 


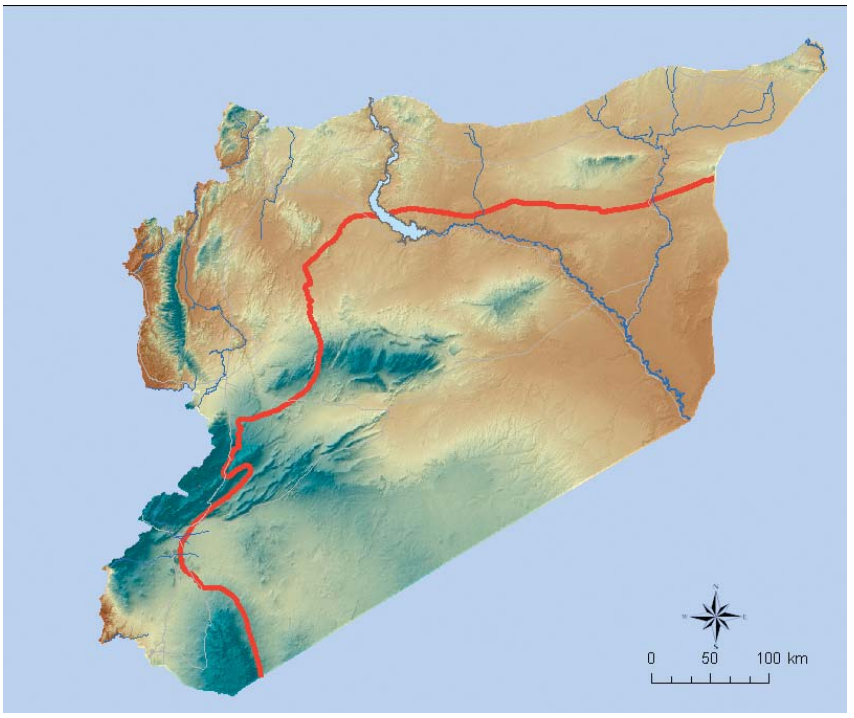

Figure 1. Map of Syria. The red line delimits areas receiving less than $200 \mathrm{~mm}$ mean annual rainfall (Badia).

scheme-ensured the revegetation process, protecting rangelands from degradation. ${ }^{12}$ Bedouin with their herds would move into the Badia at the onset of the autumn rains, when drinking water became available for livestock. When the water supply dried up at the end of the rainy season in late spring, the herds moved back to rain-fed areas, where drinking water, stubble, crop residues, fallow, and mountain grazing were available. In short, the pastoral Hema system and lack of water in the summer were probably the key factors permitting regeneration of native pastoral species. ${ }^{14}$

As part of the Hema system, the population moved over large areas, including parts of neighboring countries, ensuring that grazing areas were periodically rested. All tribes observed the Orf, traditional oral law governing rights to

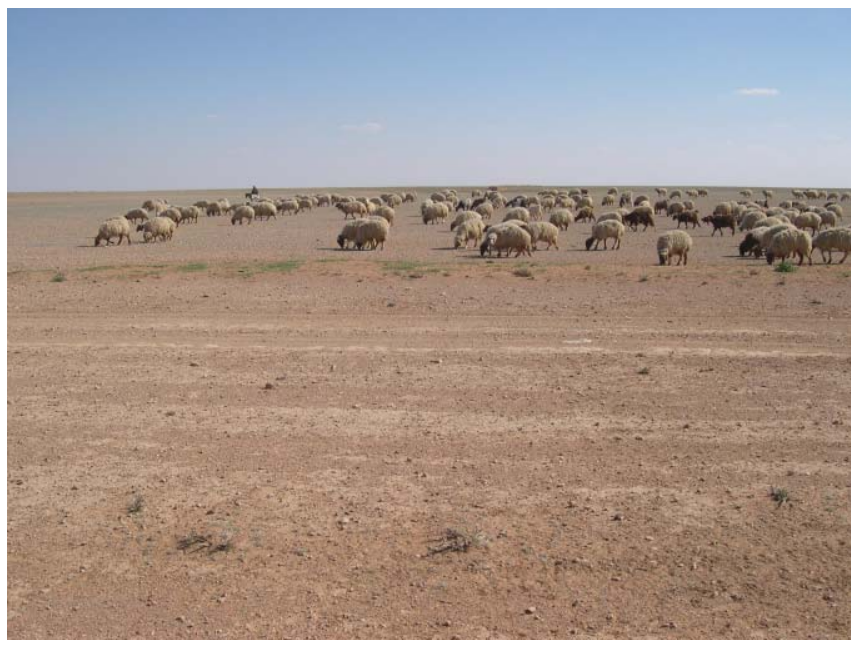

Figure 2. Flock of Awassi sheep grazing degraded rangeland in the Syrian Badia.

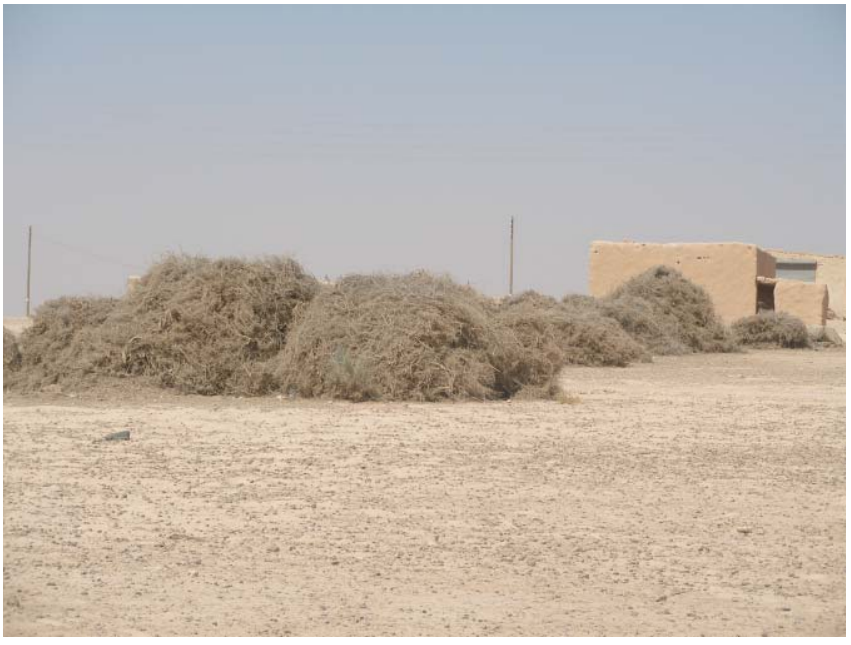

Figure 3. An unpalatable species, Noaea mucronata, which dominates the Badia rangeland, is being uprooted and gathered as fuel wood.

grazing and water, so that the resources could be accessed communally without conflict. ${ }^{10}$ Livestock were raised for subsistence, and animal numbers were subjected to environmental regulation, ensuring sustainable natural resource use. ${ }^{15}$ However, this situation has changed drastically in recent decades.

Settlement and the expansion of cultivation in Syria were initially relatively slow and occurred only in the western part of the country, up to the north-south Aleppo-Damascus road. Following the introduction of mechanization at the end of the 1940s, cultivation extended rapidly eastward. ${ }^{15}$ By the end of the 1950s, most of the land down to the 200-mm "drought line" had been brought into cultivation, changing the livestock feeding patterns as more cereal stubble became available for summer grazing.

Political realities gradually limited Bedouin mobility to Syrian territory. ${ }^{10}$ After the Second World War the government decided to permanently settle the Bedouin, under the belief that the Badia would adequately sustain rain-fed farming (Fig. 4). ${ }^{12}$ At the same time, political parties interested in gaining pastoral votes pressed the administration to free the pastoral peoples from traditional institutions controlled by sheikhs. This led to the abolishment of tribal law in 1958 and, subsequently, to the death of grazing rights (Orf). ${ }^{12}$ The Badia was declared state property with open access to grazing. This further affected tribal relationships and ability to manage land. ${ }^{7}$

After a three-year period of drought from 1958 to 1961, during which Syria's sheep population was cut in half, a system of supplementary feeding was introduced. This policy radically changed the flocks' feeding patterns. ${ }^{16}$ The government took a variety of measures to control and subsidize barley grain (the major supplementary feed) and mill byproducts, including wheat bran, cotton cake, and beet pulp. As a result, the rate of feed use increased by $25 \%, 50 \%$, and $75 \%$ in the 1960 s, 1970 s, and 1980s, respectively. ${ }^{12}$ 


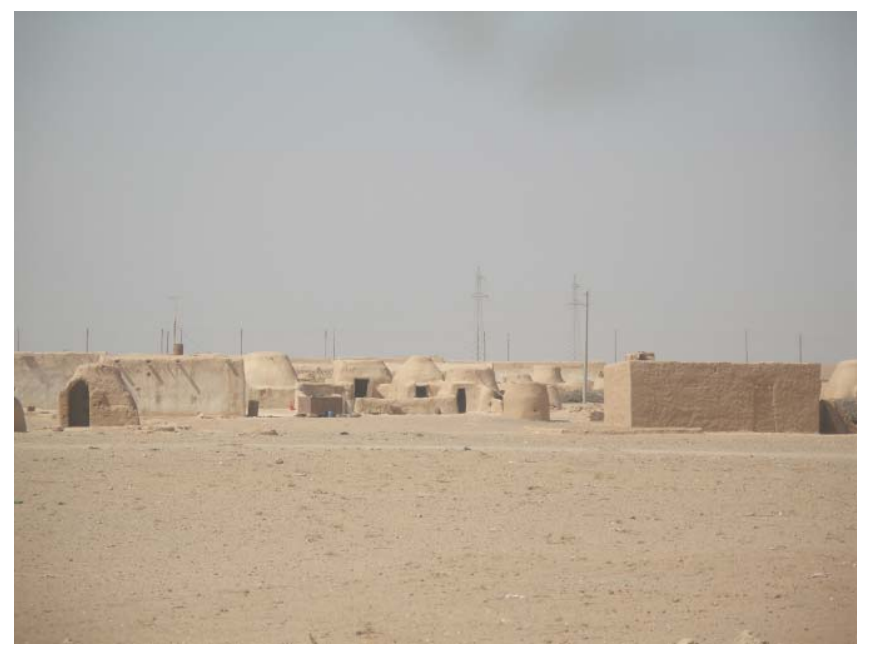

Figure 4. Typical housing "dome" for nomadic Bedouins who settled in the Syrian Badia.

The newly implemented government measures did more than simply allow the sheep herd to recover. An FAO (Food and Agriculture Organization of the United Nations) report ${ }^{17}$ on the impact of the subsidized feed policy indicated that such a policy would increase pressure on the already degraded pastures through an increase in sheep numbers. Combined with an increasing demand for animal products from a rapidly growing human population-from 4 million in 1950 to over 22 million in 2007-the result was a massive increase in pressure on rangelands. This increased pressure is clear from one fact: the number of sheep in the Badia has increased from an estimated 3 million in 1950 to over 22 million in 2007..$^{18}$

The combination of increased human and sheep populations, continued expansion of barley cultivation, and the introduction of vehicles after the 1950s all took their toll on the ecological vitality of the Badia. Degradation, combined with policy changes that affected the Bedouin's lifestyle, led to higher stocking rates and longer grazing periods at each site, resulting in even faster deterioration of rangelands. Some authors identify the replacement of allocated grazing land tenure by open access (al shi'you'e) as having opened the door for rapid degradation. ${ }^{19}$

The continuing degradation in the Badia resulted in a ban on crop cultivation in $1995 .{ }^{10}$ Populations have adapted to these changes in various ways. For example, the Bedouin have come to rely heavily on purchased feed, rented grazing, and subsidized fuel as well as off-farm income to make up income shortfalls. ${ }^{20}$ Today, livestock are raised using a combination of free-range grazing and supplemental feeding. At present, even in good rainy seasons, the Badia does not provide more than $17 \%$ of animals' annual energy requirements-equivalent to about 2 months grazing without supplementation. ${ }^{21}$ Given the current degraded condition of the Badia, Bedouin communities have modified their traditional way of life, nowadays relying heavily on resources

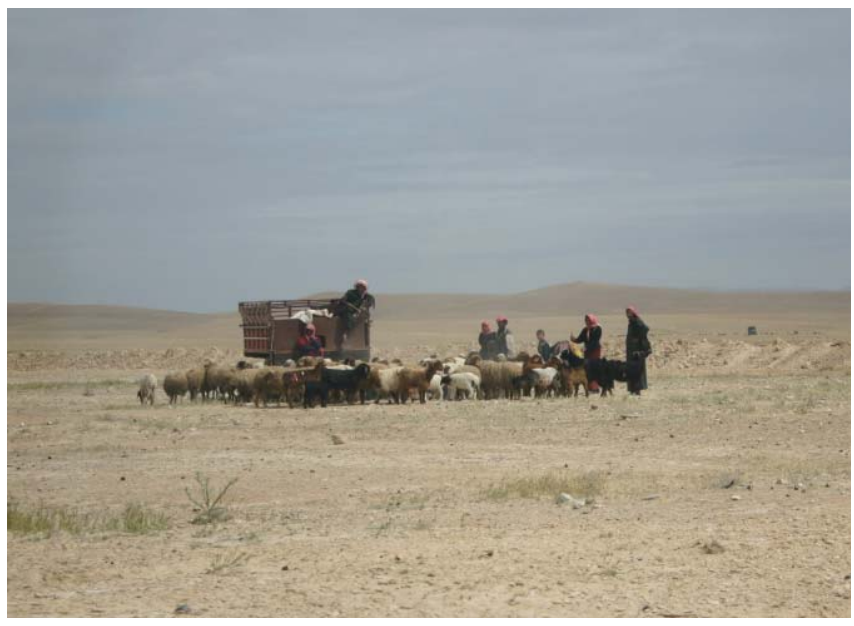

Figure 5. Bedouins use a truck to transport their herd from one location to another.

coming from outside the steppe. In fact, a large number of Bedouin now spend the majority of the year grazing their animals in other eco-regions (Fig. 5).

As a result of these various factors, natural processes in the Badia have been dramatically altered. The most widespread expression of land degradation is the decline in vegetation cover, which stems from overgrazing and fuel wood collection (Fig. 3) and is driven by the needs of growing populations. As reported by Serra et al., ${ }^{15}$ the area covered by vegetation diminishes year by year, and productivity has declined dramatically: about 50\% between 1997 and 2003. Another, more subtle, form of degradation is the change in plant species composition (i.e., the balance between annuals and perennials) to the detriment of the range and its ability to hold soil and water. ${ }^{22}$ As a result, the ecosystem also tends to become dominated by a few unpalatable species. ${ }^{9}$ Notably, both these factors-decrease in vegetative cover and change in species compositioncombine to make the Badia susceptible to erosion. This is reflected in anecdotal evidence that sandstorms are becoming more intense every year, as reported by the citizens of Palmyra. ${ }^{15}$ Furthermore, desertification in the Badia has drastically modified wildlife populations, with older Bedouin recalling that only 40 years ago, "gazelles outnumbered sheep." Today, one can travel through the steppe without seeing any wildlife at all, and the number of species extinct or threatened with extinction is on the increase. ${ }^{15}$

\section{Development Initiatives}

A number of policies and reforms have been endorsed by the Syrian government, aimed at alleviating the pressure on rangelands and the harsh conditions under which the Bedouin are living. Such initiatives address urgent needs but require substantial human and financial resources, which are provided by the Syrian government and international financial institutions. These efforts have led to considerable 


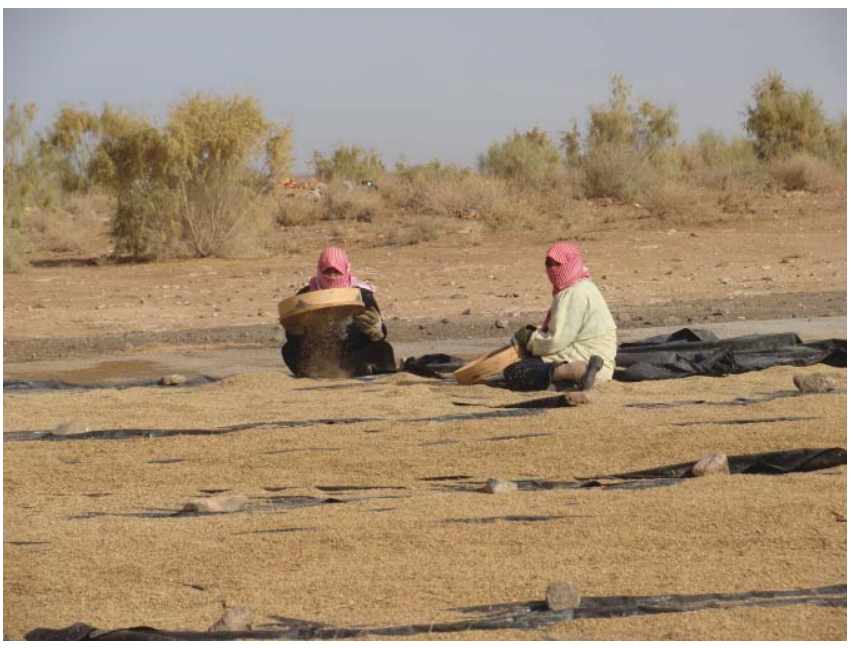

Figure 6. Large-scale seed collection and multiplication.

funding for the Badia, in particular the long-term Badia rangelands development project, which was financed by the International Fund for Agricultural Development (IFAD) in $2000 .{ }^{23}$ It aims at improving rangeland and livestock productivity, conserving the environment, controlling desertification, and enhancing the living standards of the Bedouin. ${ }^{24}$ This ongoing project has been vital in implementing a number of activities:

- Rehabilitating and managing degraded rangelands

- Establishing large-scale seed collection and multiplication facilities

- Developing livestock production systems through adoption of appropriate breeding and health management strategies, extensive rehabilitation efforts, and new employment opportunities (Fig. 6)

- Developing infrastructure, particularly water supply and rural roads

- Developing local communities through the establishment of institutional arrangements capable of implementing a fully participatory approach. The program is designed to improve the educational level and socioeconomic status of Bedouin women.

A participatory approach has been adopted that entails cooperative planning involving local leaders and governmental officials. Some local people are employed by the project, and thus there is some remuneration to community members during the implementation phase. There is also a small grazing fee initiated by the project, which is to be used for managing areas once improved sites are open for grazing. It is hoped that modern, rational management strategies developed by the project will continue once external funding is no longer available. Without intervention such as provided by this project, the majority of the Badia rangelands will likely continue to degrade at an alarming rate as more pressure is placed on them.

In 2006 a new presidential decree was signed by the government for the creation of the General Commission for Badia Development and Management (GCBDM) ${ }^{25}$ Having

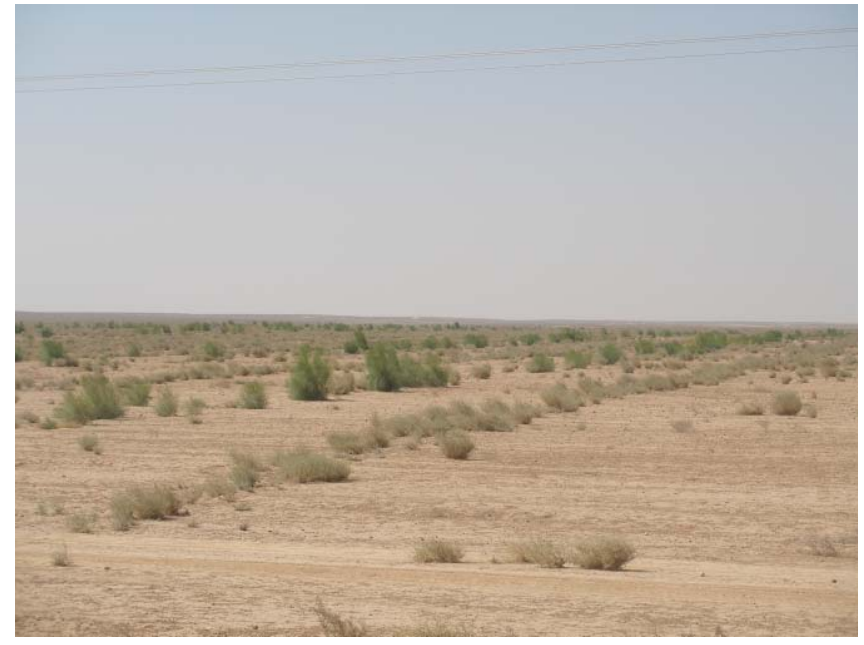

Figure 7. Shrub plantations established by the Badia project as pastoral reserves.

its headquarters in Palmyra, this body is a public legal entity and has administrative and financial independence, reporting directly to the head of the Council of Ministers. ${ }^{26}$ This institution is to consolidate various departments previously responsible for different activities in the Badia and coordinate activities by all stakeholders for economic and social development programs. Its overall goal is to develop the Badia by improving human and natural resources and developing infrastructure. To reverse steppe degradation and increase fodder production, the project will establish pastoral reserves, pastoral nurseries, deep wells, green oases, and environmental reserves, as well as stabilizing sand dunes.

\section{Future Priorities}

To further enhance the existing framework in charge of the Badia rangelands in Syria and thus promote the sustainable improvement and management of the Syrian steppes, certain issues need to be addressed. In particular, the coexistence of the Badia rangelands development project and the GCBDM is still somewhat ambiguous. Over the last decade, the Badia rangelands development project, through the IFAD funds, has acquired the necessary equipment to conduct field work, and technical staff have gained a considerable amount of experience. Ideally, all major stakeholders acting in the Badia should have clear attribution of tasks so that objectives are met.

The Badia rehabilitation efforts have focused on fodder shrub plantations (Fig. 7), including Atriplex spp., Haloxylon spp., and Salsola vermiculata. But the Badia biodiversity is much richer, encompassing several native species. Therefore, efforts should be enhanced to diversify the species composition, including herbaceous species. This latter effort would break the crusting soil surface, allowing water to infiltrate and seeds to germinate. Along the same line, safeguarding genetic resources is often not given the attention it deserves, 
particularly within the context of development projects where such studies are classified as research. There should be a strategy to conserve threatened species, assemble significant diversity of key species, and evaluate them for use as forage or pasture crops to overcome feed deficits and reverse land degradation. Other rehabilitation measures with great impact to revegetate vast areas cheaply are rest and land scarification.

A national strategy must be put in place for continuous resource inventory and monitoring, especially in the steppe environment, where an extended drought or a wet climatic episode may totally change the vegetation type and the range biomass in a short period, requiring flexible management. Range vegetation maps must be regularly updated. This will help identify the best-adapted indigenous species for rehabilitation of degraded rangelands. In this regard, remote sensing and geographic information systems provide a cost-effective method for mapping and monitoring large areas. The same tools can be used to establish an early warning system for monitoring drought, which will allow the national, or even regional, government and donor agencies to respond rapidly to and avert humanitarian crises.

For sustainable use of these natural resources, a proper grazing scheme should be designed and adopted by all users. Developing alternative forage options would enable herders to manipulate timing of rangeland use, increasing flexibility in when and how the Badia is used. This flexibility would help secure important habitat components for indigenous species. This is the most difficult part, because of the importance - and complexity - of land tenure issues in extensive communal rangelands. A sense of ownership needs to be cultivated and respected so that pastoralists will become custodians of their resource base and adopt methods that ensure long-term sustainability. The suggested actions should be developed and implemented with the participation and full support of the pastoral community.

Priority activities under these initiatives will include strengthening of Syria's rangeland development agencies, an expanded agenda for applied research, training of field staff, identifying and promoting relevant technologies, and strengthening grassroots organizations as well as educational institutions.

\section{Conclusions}

The rangeland steppe or Badia is the main source of feed, fuel wood, and medicinal herbs for Bedouin communities whose livelihoods depend on rangeland-based livestock production. These communities are experiencing change at a rate unprecedented in recent history. Past and current disturbances including overgrazing, crop encroachment, fuel wood collection, and general mismanagement have led to disastrous environmental conditions over large tracts of the Badia. If immediate action is not taken, vast areas of the
Badia could turn into desert. There is a clear and urgent need to implement ecologically sustainable rangeland management, halt the loss of biodiversity, and restore degraded landscapes.

The Badia rangelands have to be preserved or restored because they are an important element of national development. This will require not only additional research but also an appreciation of the consequences of different range policies and institutional innovations on Bedouin production systems and rangelands. Luckily, much more is now known and documented in relation to several key factors: native plant response to grazing and drought, herd mobility, and social aspects of communal rangelands. However, rangeland users and researchers must integrate current knowledge with the lessons learned from past experience as they continue the quest for sustainable rangeland livestock production in dry areas. The way forward for improving the livelihood of the Bedouin families in the Badia will depend very much on the extent to which adequate policy, institutional, and technical options are identified and used with the full participation of the communities. This will require promotion of institutional building, as well as improving applied rangeland research on numerous issues, training rangeland technicians, disseminating appropriate technologies, and most importantly developing grassroots institutions.

\section{Acknowledgments}

We gratefully acknowledge the International Center for Agricultural Research in the Dry Areas for supporting this internship. Great thanks also go to IFAD for funding this development project and to the Badia rangelands development project and the General Commission for Badia Development and Management for their valuable information and cooperation.

\section{References}

1. Nordblom, T., and S. Farouk. 1995. Food and feed prospects to 2020 in the West Asia/North Africa Region. ICARDA, Social Science Papers No. 2. Aleppo, Syria: ICARDA. 56 p.

2. Al-Kнатів, M. 2008. The current status of rangelands in Syria and project programs for developments. Proceedings of the 48th Annual Science Week conference on The Animal Wealth in Syria: Current Status and Prospects for Future Development; 17-20 November; Aleppo University, Aleppo, Syria. p. 194-195.

3. Jaubert, R. 1991. Transformations et extension des systèmes de cultures au détriment des steppes: la destruction des steppes syriennes. Colloque International, Devenir des Steppes d'Arabie et du Bilad Ach-Cham; 10-13 April; Arab World Institute, Paris, France.

4. Sincich, F. 2002. Bedouin traditional medicine in the Syrian steppe. Rome, Italy: FAO Plant Production and Protection Division. p. 114-115.

5. Chatelard, G. 2005. Desert tourism as a substitute for pastoralism? Tuareg in Algeria and Bedouin in Jordan. In: D. Chatty 
[ED.]. Nomadic societies in the Middle East and North Africa: entering the 21st century. Handbook of Oriental studies series. Leiden, the Netherlands: Brill. p. 710-736.

6. Dutilly, D. C., N. McCarthy, F. Turkelboom, A. Bruggeman, J. Tiedemann, K. Street, and G. Serra. 2007. Could payments for environmental services improve rangeland management in Central Asia, West Asia and North Africa? CAPRi Working Paper 62. Washington, DC, USA: IFPRI. 42 p.

7. Salkini, K. A., M. Audat, and M. Louhaichi. 2008. Rehabilitation of degraded rangelands: case study of Khanasser Valley. Proceedings of the 48th Annual Science Week conference on The Animal Wealth in Syria: Current Status and Prospects for Future Development; 17-20 November; Aleppo University, Aleppo, Syria. p. 205-206.

8. Le Houerou, H. M. 1993. Grazing lands of the Mediterranean basin. In: R. T. Coupland [ED.]. Natural grasslands, eastern hemisphere. Ecosystems of the world, vol. 8 B. Amsterdam, the Netherlands: Elsevier Scientific Publishers. p. 171-196.

9. Zoebisch, M., And Z. Masri. 2002. Natural restoration of degraded grazing land. Symposium No. 46, Paper No. 1524, 17th WCSS; 14-21 August 2002; Bangkok, Thailand.

10. Dutilly-Diane, C., F. Ghassali, N. Batikha, G. Arab, E. Khoudary, C. Saint-Macary, J. A. Tiedeman, and M. Louhaichi. 2006. Al Badia community survey in Syria: descriptive statistics. Aleppo, Syria: ICARDA Publication. 100 p.

11. USDA. 1999. Keys to soil taxonomy. Washington, DC, USA: Soil Survey Staff, USDA. 600 p.

12. Masri, A. 2001. Country pasture/forage resource profiles: Syria. FAO, Grassland and Pasture Crops Group. Available at: http://www.fao.org/ag/AGP/AGPC/doc/Counprof/syria/ syria.htm. Accessed 22 December 2008.

13. Leybourne, M., R. Jaubert, and R. N. Tutwiler. 1993. Changes in migration and feeding patterns among seminomadic pastoralists in Northern Syria. Pastoral Development Network Paper 34a. London, United Kingdom: Overseas Development Institute. 20 p.

14. Draz, O. 1978. Revival of Hema system of range reserves, as basis for Syrian range development programmes. Proceedings of First International Range Management Conference; Denver, CO, USA. p. 100-103.

15. Serra, G., D. Williamson, and C. Batello. 2003. From indifference to awareness: encountering biodiversity in the semi-arid rangelands of the Syrian Arab Republic. FAO Interdepartmental Working Group on Biological Diversity for Food and Agriculture. Rome, Italy: FAO. 47 p.

16. Lewis, N. 1987. Nomads and settlers in Syria and Jordan 1800-1980. Cambridge, United Kingdom: Cambridge University Press. 266 p.
17. Mirreh, M., A. Arru, and C. Batello. 2000. Towards formulation of drought management policies and strategies. FAO/ GCP /SYR/ 009/ITA. Rome, Italy: FAO. 32 p.

18. Ministry of Agriculture and Agrarian Reform (MAAR). 2008. The annual agricultural statistical abstract 2007. Damascus, Syria: Department of Planning and Statistics, Division of Agricultural Statistics. 238 p.

19. Al-Aвid, N. D. 2000. Evaluation of direct and indirect economic and environment impacts on desertification: case study of Jabel Al-Bechir, Syrian Badia. Sofia, Belgrade: ACSAD. 20 p.

20. Findlay, A. M. 1996. Population and environment in arid regions. International Union for the Scientific Study of Population. Policy Paper 10. Liége, Belgium: IUSSP. 21 p.

21. Al-Sheick, A. 2008. Current position of fodder and fodder stock administration in Syria. Proceedings of the 48th Annual Science Week conference on The Animal Wealth in Syria: Current Status and Prospects for Future Development; 17-20 November; Aleppo University, Aleppo, Syria. p. 135-136.

22. Louhaichi, M., A. K. Salkini, and S. L. Petersen. 2009. Effect of small ruminant grazing on the plant community characteristics of semiarid Mediterranean ecosystems. International Journal of Agriculture E Biology 11:681-689.

23. International Fund for Agricultural Development. 2010. Syria: Badia Rangelands Development Project. Available at: http://www.ifad.org//rkm/region/pn/sy_1073.htm. Accessed 22 February 2010.

24. Каzah, I. 2008. The role of Badia development project in rangeland development by applying the participatory approach. Proceedings of the 48th Annual Science Week conference on The Animal Wealth in Syria: Current Status and Prospects for Future Development; 17-20 November; Aleppo University, Aleppo, Syria. p. 199-202.

25. Hammoud, A. 2008. Development programs for natural rangelands in the Syrian steppe. Proceedings of the 48th Annual Science Week conference on The Animal Wealth in Syria: Current Status and Prospects for Future Development; 17-20 November; Aleppo University, Aleppo, Syria. p. 196-198.

26. General Commission for Badia Development and Management. 2010. Establishment decrees. Available at: http://www.badiasy.com/homepage.html. Accessed 22 February 2010.

Authors are Rangeland Scientist, International Center for Agricultural Research in the Dry Areas (ICARDA), PO Box 5466, Aleppo, Syria, M.Louhaichi@cgiar.org (Louhaichi); and Undergraduate Student, University of Saskatcherwan, Saskatoon, SK S7H OA1, Canada (Tastad). 